\title{
A novel peptide blocking cancer cell invasion by structure-based drug design
}

\author{
YUKI YAMADA $^{1}$, SEIJI KANAYAMA ${ }^{1}$, FUMINORI ITO ${ }^{1}$, NORIYUKI KURITA ${ }^{2}$ and HIROSHI KOBAYASHI ${ }^{1}$ \\ ${ }^{1}$ Department of Obstetrics and Gynecology, Nara Medical University, Kashihara 634-8522; \\ ${ }^{2}$ Department of Computer Science of Engineering, Toyohashi University of Technology, Toyohashi 441-8580, Japan
}

Received July 15, 2017; Accepted July 31, 2017

DOI: 10.3892/br.2017.957

\begin{abstract}
The receptor for the urokinase-type plasminogen activator (UPA), UPAR, facilitates tumor cell invasion and metastasis by focusing on several ligands, including uPA, integrins and vitronectin. With computational prediction algorithms and structure-based drug design, we identified peptides containing the Gly-Lys-Gly-Glu-Gly-Glu-Gly-Lys-Gly sequence (peptide H1), which strongly interacts with uPAR. The aim of the present study was to investigate the effect of allosteric inhibition at the UPAR interface using a novel synthetic peptide and its function on ovarian cancer cell invasion. The molecular and functional mechanisms of $\mathrm{H} 1$ were determined by complementary biochemical and biological methods in the promyeloid U937 cell line as well as ovarian cancer cell lines, including serous carcinoma SKOV3 and clear cell carcinoma TOV21G. The effects of $\mathrm{H} 1$ treatment on cancer cell invasion were evaluated in vitro. $\mathrm{H} 1$ inhibited cancer cell invasion, without affecting cell viability, accompanied by the suppression of extracellular signal-regulated kinase (ERK)-1 phosphorylation and then matrix metalloproteinase (MMP)-9 expression. H1 failed to block the interaction of UPA-uPAR protein-protein interaction in cells, but antagonized the UPA function. H1 failed to disrupt the UPA-uPAR complex, but abolished the invasion of ovarian cancer cells at least through suppression of the ERK-MMP-9 signaling pathway. Further studies are needed to confirm our observations and to describe the underlying molecular mechanism.
\end{abstract}

\section{Introduction}

Epithelial ovarian cancer has the highest mortality rate among all the gynecologic tumors (1). Recent advances in molecular technologies have made possible the creation of personalized

Correspondence to: Dr Hiroshi Kobayashi, Department of Obstetrics and Gynecology, Nara Medical University, 840 Shijo-cho, Kashihara 634-8522, Japan

E-mail: hirokoba@naramed-u.ac.jp

Key words: structure-based drug design, ovarian cancer, invasion, uPAR, synthetic peptide medicine, but peritoneal dissemination is associated with poor overall survival of ovarian cancer patients (1-3). Despite some improvements in treatment, current therapy is not considered curative as the mechanism underlying the peritoneal dissemination remains unclear. To overcome a poor clinical prognosis, understanding the molecular and functional mechanisms involved in the ovarian cancer cell survival, proliferation, invasion, dissemination and metastasis is of great physiological and clinical importance.

Members of the plasminogen activator system including urokinase-type plasminogen activator (uPA) and its receptor UPAR are overexpressed on the surfaces of a wide range of invasive cancer cells, including those of the prostate, brain, breast and colon in addition to ovarian cancer (2). uPAR may be a more aggressive phenotype in a broad range of human various aggressive cancer types, including ovarian cancer (3). uPAR is a glycosyl phosphatidylinositol-anchored cell surface receptor that interacts with uPA and other molecules, such as integrins and vitronectin (VN). Accumulating evidence shows that the UPA-uPAR system, such as uPAR activation and its downstream signaling, is associated with cancer progression, invasion, metastasis and peritoneal dissemination in a variety of tumor types $(2,3)$. uPAR activates diverse signaling pathways, including phosphorylation of extracellular signal-regulated kinase (ERK) and then stimulation of matrix metalloproteinase (MMP)-9 expression $(4,5)$.

Notably, multiple approaches to inhibit the uPA-uPAR system may suppress cancer cell invasion and induce cell death. Indeed, various treatment strategies including selective inhibitors of uPA activity (6-13), specific antagonistic peptides that block uPA-uPAR protein-protein interaction (13-24), shRNA-uPAR-mediated silencing (5,25-32), or inhibitory antibodies against UPA or UPAR (33-36) have been investigated in promising preclinical and clinical trials. Although uPAR promotes cancer progression independently of protease activation, scavenging the active uPA or blocking its function leads to reduced tumor progression and may show be promising for prolonging patient survival (37). Anti-uPAR antibodies preventing uPA binding to UPAR can potentially lead to the suppression of cancer invasion. Functional analysis using shRNA-uPAR transfected to downregulate uPAR revealed a critical role for UPAR in cancer invasion and metastasis. The synthetic peptides that prevent UPA-uPAR interaction are a promising template for designing novel peptide-based small 
compounds to provide an effective strategy to treat ovarian cancer (17).

Furthermore, uPAR interacts with not only uPA, but also several molecules, such as VN, integrins, caveolin-1, $\mathrm{G}$ protein-coupled receptors (formyl peptide receptor 2), low density lipoprotein receptor-related protein 1 and epidermal growth factor receptor $(38,39)$. Integrins are the important transmembrane binding partners associated with uPAR, leading to integrin-mediated intracellular signaling. Integrins also serve as VN receptors and binding of VN to integrins results in the uPA-mediated cell invasion via uPAR (40). uPAR-integrin signaling to ERK increases the expression of MMPs through AP1 transcription factors (39-41).

Computer simulations can provide a dry lab experience that may fulfil some of the objectives of the in vitro wet labs. We reported previously that structure-based computational docking study using ab initio molecular orbital calculations has predicted co-binding of the omega-loop of amino-terminal fragment of uPA with the positively charged 46, 61 and 98 Lys residues of uPAR $(42,43)$. Molecular dynamics computer simulation by structure-based drug design revealed that the single 9-residue amino acid peptide with the Gly-Lys-GlyGlu-Gly-Glu-Gly-Lys-Gly sequence (peptide H1) has a large binding energy to uPAR that may block the binding between uPAR and some ligands, uPA or VN $(42,43)$. In the present study, we synthesized $\mathrm{H} 1$ as a potent UPAR inhibitor and control peptide (an amino acid sequence-shuffled peptide).

The aims of this study were to investigate whether cancer cells depend on the function of UPAR for their invasion and whether $\mathrm{H} 1$ specifically inhibits cell invasion in vitro.

\section{Materials and methods}

Materials. The materials used in the present study and the manufacturers providing them are as following: anti-total ERK1/2, anti-phospho-p44/42 ERK, anti-MMP-9, anti- $\beta$-actin (no. 4967) (all from Cell Signaling Technology, Inc., Danvers, MA, USA), the horseradish peroxidase-conjugated secondary antibodies from Sigma-Aldrich (St. Louis, MO, USA), human uPA from Chemicon International, Inc. (Temecula, CA, USA) and American Diagnostica (Lexington, MA, USA) fluorescein isothiocyanate (FITC)-conjugated uPA from Abcam (cat. no. ab9152; Cambridge, UK) and 3-(4,5-dimethylthiazol-2yl)-2,5-diphenyl tetrazolium bromide (MTT) powder from Roche Diagnostics (Indianapolis, IN, USA). Plastic ware was purchased from Costar (Cambridge, MA, USA). The protein content was determined using a bicinchoninic acid assay (Pierce Biotechnology, Inc., Rockford, IL, USA). Linear peptides, H1 (Gly-Lys-Gly-Glu-Gly-Glu-Gly-Lys-Gly) and H2 (Glu-Gly-Gly-Lys-Glu-Lys-Gly-Gly-Gly; an amino acid sequence-shuffled control peptide), were synthesized and HPLC-purified as described (Peptide Institute, Inc., Osaka, Japan) (44).

Flow cytometry. Promyeloid leukemia U937 cells, stimulated for $48 \mathrm{~h}$ with phorbol-12 myristate-13-acetate (PMA; $1 \mathrm{mmol} / \mathrm{l}$ ), were used to investigate binding of $\mathrm{H} 1$ and $\mathrm{H} 2$ peptides to cellassociated uPAR. Cells $\left(2.5 \times 10^{5}\right)$ were washed several times with phosphate-buffered saline (PBS) supplemented with $0.1 \%$ bovine serum albumin (BSA) and then subjected to acidic buffer (50 mmol/1 glycine/HCI, pH 3.0, for $1 \mathrm{~min}$ ) to remove receptor-bound endogenous uPA, followed by a neutralization step with $0.5 \mathrm{~mol} / 1 \mathrm{HEPES} / \mathrm{NaOH}$, pH 7.5 (45). The cells were subsequently incubated with increasing amounts of $\mathrm{H} 1$ peptide or $\mathrm{H} 2$ peptide ( 0 or $1,000 \mathrm{nM}$ ) in the presence of $2 \mu \mathrm{g}$ of FITC-labeled uPA for $30 \mathrm{~min}$. The cells were washed again with PBS/0.1\% BSA. The cell-associated fluorescence was determined.

Cell culture. Human ovarian carcinoma cell lines SKOV3 (serous-type) and TOV21G (clear cell-type) cells were purchased from the American Type Culture Collection (Manassas, VA, USA). The cells were cultured in Dulbecco's modified Eagle's medium/F12, supplemented with $10 \%$ fetal bovine serum and $100 \mathrm{U} / \mathrm{ml}$ penicillin/streptomycin (all from Invitrogen Life Technologies, Carlsbad, CA, USA) in a humidified incubator with $5 \% \mathrm{CO}_{2}$ and $95 \%$ air at $37^{\circ} \mathrm{C}$.

Western blot analysis. Cells were washed 3 times with ice-cold PBS and extracted in ice-cold lysis buffer containing $50 \mathrm{mM}$ Tris- $\mathrm{HCl}$ (pH 8.0), 1\% Nonidet 40, $0.5 \mathrm{mM}$ ethylenediaminetetraacetic acid, $100 \mu \mathrm{g} / \mathrm{ml}$ phenylmethysulfonyl fluoride, $2 \mu \mathrm{g} / \mathrm{ml}$ leupeptin, $100 \mu \mathrm{m}$ sodium vanadate, $1 \mathrm{mM}$ dithiothreitol, $1 \mu \mathrm{g} / \mathrm{ml}$ aprotinin and $150 \mathrm{mM} \mathrm{NaCl}$ for $30 \mathrm{~min}$. The equal amount of protein was separated on $10 \%$ sodium dodecyl sulfate-polyacrylamide gel and then transferred to a nitrocellulose membrane (EMD Millipore, Billerica, MA, USA). The membrane was incubated with phospho-ERK, total ERK, uPAR, or MMP-9 (46). Proteins were visualized using an enhanced chemiluminescence kit (Pierce Biotechnology, Inc.). The blots were quantified by densitometry with the Quantity One software (Bio-Rad Laboratories, Inc., Hercules, CA, USA).

MTS cell viability assay. The effects of synthetic peptides on cell viability were estimated using an MTS assay kit (Promega Corp., Madison, WI, USA) (47). After the H1 or H2 treatment, MTS solution was added to each well for $2 \mathrm{~h}$ at $37^{\circ} \mathrm{C}$ in $5 \% \mathrm{CO}_{2}$. The absorbance at $490 \mathrm{~nm}$ was recorded using a GloMaxMulti+Microplate Multimode Reader (Promega Corp.).

Transwell invasion assay. Transwell plates (24-well) (Costar Inc., Corning, NY, USA) were coated with $30 \mu \mathrm{g} / \mathrm{ml}$ of Matrigel at $4^{\circ} \mathrm{C}$ overnight. After $16 \mathrm{~h}$ of serum starvation, $5 \times 10^{4}$ cells in $250 \mu \mathrm{l}$ of $0.1 \%$ FBS medium containing $10 \mathrm{nM}$ uPA in the presence of the indicated $\mathrm{H} 1$ peptide or $\mathrm{H} 2$ control peptide were added to the upper chamber and incubated at $37^{\circ} \mathrm{C}$ for $22 \mathrm{~h}$. A total of $500 \mu \mathrm{l}$ of $10 \%$ FBS medium containing the same amount of compounds was simultaneously added to the lower chamber. Non-migrated cells on the top of the transwell were scrapped off with a cotton swab and the number of migrated cells was counted in ten separate fields and averaged across two independent experiments with each concentration in triplicate. We confirmed some results of cell invasion experiments by a novel protocol utilizing the IncuCyte ZOOM instrument (Essen Bioscience, Ann Arbor, MI, USA).

Statistical analysis. The bar graphs are the means \pm standard deviation from at least three independent experiments. Comparison of mean values between 2 groups was evaluated 
by the t-test. For all statistical methods, a $\mathrm{P}<0.05$ was considered to indicate a statistically significant difference.

\section{Results}

Characterization of $\mathrm{H} 1$ peptide. We synthesized peptides $\mathrm{H} 1$ and $\mathrm{H} 2$. H2 peptide (control) is the amino acid sequence-shufled H1 peptide. We employed a flow cytometry assay using FITC-conjugated uPA to assess whether H1 blocks the uPA-uPAR protein-protein interaction in U937 cells. Free uPA protein significantly inhibited the FITC-labeled uPA protein binding to the uPAR on the U937 cells in a dose-dependent manner, but both $\mathrm{H} 1$ and $\mathrm{H} 2$ failed to disrupt the interactions between FITC-labeled uPA and cellular UPAR (Fig. 1).

H1 impairs invasion of ovarian cancer cells in vitro. We then determined whether $\mathrm{H} 1$ inhibits ovarian cancer cell invasion. Cells were serum-starved for $16 \mathrm{~h}$ and then treated with $10 \mathrm{nM}$ uPA at $37^{\circ} \mathrm{C}$ for the indicated times. SKOV3 and TOV21G cells were treated with $10 \mathrm{nM}$ uPA in the presence or absence of increasing concentrations of $\mathrm{H} 1$ or $\mathrm{H} 2$ for $22 \mathrm{~h}$. $\mathrm{H} 1$ was effective in suppression of the invasion in a dose-dependent manner in cancer cells with $\mathrm{IC}_{50}$ values of approximately $100 \mathrm{nM}$ (Fig. 2). H2 showed no effect on cell invasion. H1 has also similar inhibitory effects on TOV21G cells (data not shown).

Cell viability. We performed MTS assays in SKOV3 and TOV21G with increasing concentrations of $\mathrm{H} 1$ or $\mathrm{H} 2$ (1,000 nM) for $24 \mathrm{~h}$. H1 and H2 peptides did not affect the viability and growth of SKOV3 cells (data not shown). Similar results were obtained after treatment with each peptide in TOV21G cells.

H1 abolishes uPA-induced ERK phosphorylation and subsequent activation of MMP-9 overexpression. To investigate the underlying mechanism of action for the cell invasion inhibition of H1, we selected SKOV3 cell lines for further investigation. SKOV3 cells were serum-starved for $16 \mathrm{~h}$ and then pretreated with different concentrations (100 and 1,000 nM) of $\mathrm{H} 1$ or $\mathrm{H} 2$. After $30 \mathrm{~min}$, the cells were incubated for another $5 \mathrm{~min}$ with $10 \mathrm{nM}$ uPA. Phosphorylated and total ERK were detected by western blot analysis. $\mathrm{H} 1$, but not $\mathrm{H} 2$, significantly suppressed the uPA-induced phosphorylation of ERK in a dose-dependent manner (Fig. 3A).

Next we examined whether $\mathrm{H} 1$ was able to suppress the uPA-induced MMP-9 expression through inactivation of the ERK pathway. Treatment for 24 h of SKOV3 cells with $\mathrm{H} 1$ resulted in dose-dependent suppression of MMP-9 expression, starting at a concentration of $100 \mathrm{nM}$ (Fig. 3B). H2 did not reduce the expression of MMP-9.

\section{Discussion}

In a previous in silico study, we designed small molecule inhibitors of the uPAR-ligand interaction by molecular docking and molecular dynamic simulation studies (43). Compound $\mathrm{H} 1$ was selected and identified using $a b$ initio molecular simulation method $(42,43)$. Since our previous studies were fully dependent on computational prediction algorithms, the function of $\mathrm{H} 1$ was confirmed by wet lab

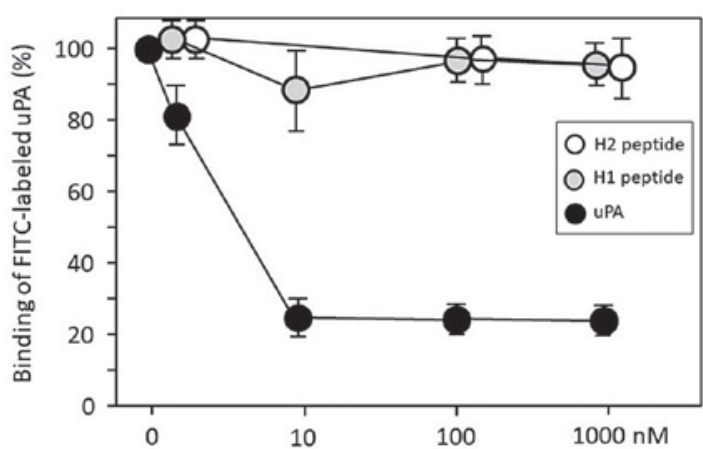

Figure 1. Suppression of FITC-labeled uPA binding to uPAR on the U937 cell surface by uPA, H1 and H2. PMA-stimulated U937 cells were incubated with different concentrations (10, 100 and 1,000 nM) of uPA, H1 or H2 followed by incubation with FITC-labeled uPA. x-axis, concentration (nM); y-axis, binding of FITC-labeled uPA (\%). The flow cytometry was representative of three independent experiments. FITC, fluorescein isothiocyanate; uPA, urokinase-type plasminogen activator.

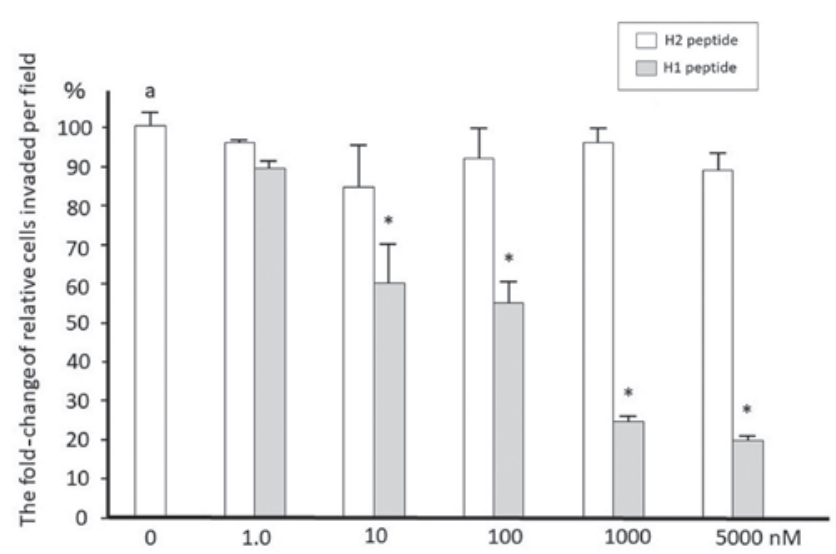

Figure 2. The effect of H1 on SKOV3 cell invasion. Quantification of matrige invasion assay showing the in vitro invasion of SKOV3 cells. H1 suppressed the invasion of SKOV3 cells in a dose-dependent manner. $\mathrm{x}$-axis, concentration (nM); $\mathrm{y}$-axis, the fold-change of relative cells invaded per field. ${ }^{*} \mathrm{P}<0.05$ vs. ${ }^{a}(0 \mathrm{nM})$.

A

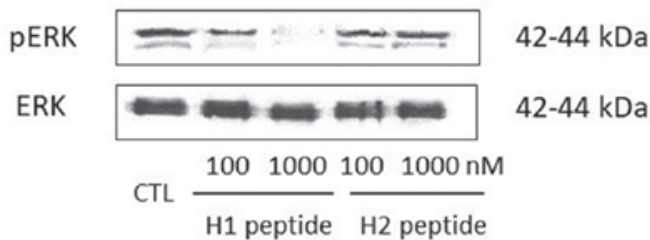

B
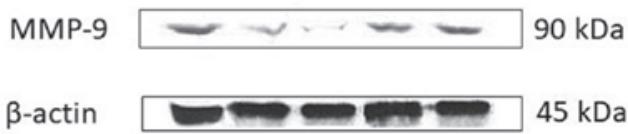

$$
\text { CTL } \frac{1001000}{\mathrm{H} 1 \text { peptide }} \frac{1001000 \mathrm{nM}}{\mathrm{H} 2 \text { peptide }}
$$

Figure 3. H1 suppresses uPA-induced expression of phosphorylated ERK and MMP-9 in SKOV3 cells. SKOV3 cells pretreated with indicated concentration of $\mathrm{H} 1$ or $\mathrm{H} 2$ were incubated with $10 \mathrm{nM}$ uPA and cell lysates were analyzed for the (A) phosphorylated and total p42/44 as well as (B) MMP-9 and $\beta$-actin by western blot analysis. The immunoblots are representative of three independent experiments. ERK, extracellular signal-regulated kinase; MMP, matrix metalloproteinase; uPA, urokinase-type plasminogen activator. 
experiments. Our results demonstrated that $\mathrm{H} 1$ significantly inhibited the uPA-dependent cell invasion, possibly though suppression of ERK-activated MMP-9 expression (Fig. 2). The inhibition of cell invasion occurs at high nano-molar concentrations. Importantly, the amino acid sequence-shuffled $\mathrm{H} 2$ peptide exhibited no effect on uPA-dependent cell invasion. The compound did not affect cell viability and its potency is independent of the inhibition of cell growth. This may provide promising evidence for the therapeutic potential of $\mathrm{H} 1$ against ovarian cancer cells. Of note, $\mathrm{H} 1$ failed to inhibit uPA binding to the UPAR, but mitigated the uPAR-dependent signaling pathway. We suggested that $\mathrm{H} 1$ and $\mathrm{uPA}$ would bind at distinct sites on uPAR molecule. However, H1 did not block the binding of VN to uPAR protein (data not shown).

Several researchers have identified, synthesized and preclinically examined several compounds acting as potential inhibitors of the uPA-uPAR interaction. The following are currently promising anti-invasive/metastatic agents: protease inhibitors $(8,13)$, small molecular peptides $(13-17,24)$, antibodies $(34,36)$ and siRNA/shRNA $(5-25,32)$. Some of these have been evaluated in in vivo pharmacokinetic and efficacy studies in an animal cancer metastasis model. These promising findings demonstrate the therapeutic potential of this synthetic $\mathrm{H} 1$ peptide against ovarian cancer and require further preclinical investigations. However, the effect on invasion of this active peptide was inconsistent with its ability to inhibit the interaction between uPA and UPAR.

In conclusion, $\mathrm{H} 1$ is a promising template for the development of orally bioavailable compounds with greater efficacy on cancer cell invasion. Further studies are needed to evaluate the molecular mechanism of $\mathrm{H} 1$ peptide.

\section{Acknowledgements}

The present study was supported by Grant-in-Aid for Scientific Research from the Ministry of Education, Science and Culture of Japan to the Department of Obstetrics and Gynecology, Nara Medical University (awarded to H.K.).

\section{References}

1. Siegel R, Naishadham D and Jemal A: Cancer statistics, 2013 CA Cancer J Clin 63: 11-30, 2013.

2. Bifulco K, Votta G, Ingangi V, Di Carluccio G, Rea D, Losito S, Montuori N, Ragno P, Stoppelli MP, Arra, C et al: Urokinase receptor promotes ovarian cancer cell dissemination through its 84-95 sequence. Oncotarget 5: 4154-4169, 2014.

3. Noh H, Hong S and Huang S: Role of urokinase receptor in tumor progression and development. Theranostics 3: 487-495, 2013.

4. Ahmad A, Kong D, Sarkar SH, Wang Z, Banerjee S and Sarkar FH: Inactivation of UPA and its receptor uPAR by 3,3'-diindolylmethane (DIM) leads to the inhibition of prostate cancer cell growth and migration. J Cell Biochem 107: 516-527, 2009.

5. Gondi CS, Lakka SS, Dinh DH, Olivero WC, Gujrati M and Rao JS: Downregulation of uPA, uPAR and MMP-9 using small, interfering, hairpin RNA (siRNA) inhibits glioma cell invasion, angiogenesis and tumor growth. Neuron Glia Biol 1: 165-176, 2004.

6. Ghamande SA, Silverman MH, Huh W, Behbakht K, Ball G, Cuasay L, Würtz SO, Brunner N and Gold MA: A phase 2, randomized, double-blind, placebo-controlled trial of clinical activity and safety of subcutaneous A6 in women with asymptomatic CA125 progression after first-line chemotherapy of epithelial ovarian cancer. Gynecol Oncol 111: 89-94, 2008.

7. Kobayashi H, Ohi H, Sugimura M, Shinohara H, Fujii $\mathrm{T}$ and Terao T: Inhibition of in vitro ovarian cancer cell invasion by modulation of urokinase-type plasminogen activator and cathepsin B. Cancer Res 52: 3610-3614, 1992.
8. Towle MJ, Lee A, Maduakor EC, Schwartz CE, Bridges AJ and Littlefield BA: Inhibition of urokinase by 4 -substituted benzo[b] thiophene-2-carboxamidines: An important new class of selective synthetic urokinase inhibitor. Cancer Res 53: 2553-2559, 1993.

9. Todaro LB, Ladeda V, Bal de Kier Joffé E and Farías EF: Combined treatment with verapamil, a calcium channel blocker, and B428, a synthetic uPA inhibitor, impairs the metastatic ability of a murine mammary carcinoma. Oncol Rep 10: 725-732, 2003.

10. Ertongur S, Lang S, Mack B, Wosikowski K, Muehlenweg B and Gires O: Inhibition of the invasion capacity of carcinoma cells by WX-UK1, a novel synthetic inhibitor of the urokinase-type plasminogen activator system. Int J Cancer 110: 815-824, 2004.

11. Evans DM and Sloan-Stakleff K: Suppression of the invasive capacity of human breast cancer cells by inhibition of urokinase plasminogen activator via amiloride and B428. Am Surg 66: $460-464,2000$

12. Henneke I, Greschus S, Savai R, Korfei M, Markart P, Mahavadi P, Schermuly RT, Wygrecka M, Stürzebecher J, Seeger W, et al: Inhibition of urokinase activity reduces primary tumor growth and metastasis formation in a murine lung carcinoma model. Am J Respir Crit Care Med 181: 611-619, 2010.

13. Lund IK, Illemann M, Thurison T, Christensen IJ and Høyer-Hansen G: uPAR as anti-cancer target: Evaluation of biomarker potential, histological localization, and antibody-based therapy. Curr Drug Targets 12: 1744-1760, 2011.

14. Mohanam S, Chandrasekar N, Yanamandra N, Khawar S, Mirza F, Dinh DH, Olivero WC and Rao JS: Modulation of invasive properties of human glioblastoma cells stably expressing amino-terminal fragment of urokinase-type plasminogen activator. Oncogene 21: 7824-7830, 2002.

15. Bürgle M, Koppitz M, Riemer C, Kessler H, König B, Weidle UH, Kellermann J, Lottspeich F, Graeff H, Schmitt M, et al: Inhibition of the interaction of urokinase-type plasminogen activator (uPA) with its receptor (UPAR) by synthetic peptides. Biol Chem 378: 231-237, 1997.

16. Sato S, Kopitz C, Schmalix WA, Muehlenweg B, Kessler H, Schmitt M, Krüger A, Magdolen V, et al: High-affinity urokinase-derived cyclic peptides inhibiting urokinase/urokinase receptor-interaction: effects on tumor growth and spread. FEBS Lett 528: 212-216, 2002.

17. Mani T, Wang F, Knabe WE, Sinn AL, Khanna M, Jo I, Sandusky GE, Sledge GW Jr, Jones DR, Khanna R, et al: Small-molecule inhibition of the uPAR.uPA interaction: Synthesis, biochemical, cellular, in vivo pharmacokinetics and efficacy studies in breast cancer metastasis. Bioorg Med Chem 21: 2145-2155, 2013.

18. Wilhelm O, Weidle U, Höhl S, Rettenberger P, Schmitt M and Graeff H: Recombinant soluble urokinase receptor as a scavenger for urokinase-type plasminogen activator (uPA). Inhibition of proliferation and invasion of human ovarian cancer cells. FEBS Lett 337: 131-134, 1994.

19. Kobayashi H, Gotoh J, Fujie M, Shinohara H, Moniwa N and Terao T: Inhibition of metastasis of Lewis lung carcinoma by a synthetic peptide within growth factor-like domain of urokinase in the experimental and spontaneous metastasis model. Int $\mathrm{J}$ Cancer 57: 727-733, 1994.

20. Min HY, Doyle LV, Vitt CR, Zandonella CL, Stratton-Thomas JR, Shuman MA and Rosenberg S: Urokinase receptor antagonists inhibit angiogenesis and primary tumor growth in syngeneic mice. Cancer Res 56: 2428-2433, 1996.

21. Weidle UH and König B: Urokinase receptor antagonists: Novel agents for the treatment of cancer. Expert Opin Investig Drugs 7: 391-403, 1998.

22. Guo Y, Higazi AA, Arakelian A, Sachais BS, Cines D, Goldfarb RH, Jones TR, Kwaan H, Mazar AP and Rabbani SA: A peptide derived from the nonreceptor binding region of urokinase plasminogen activator (uPA) inhibits tumor progression and angiogenesis and induces tumor cell death in vivo. FASEB J 14: 1400-1410, 2000.

23. Li H, Soria C, Griscelli F, Opolon P, Soria J, Yeh P, Legrand C, Vannier JP, Belin D, Perricaudet M, et al: Amino-terminal fragment of urokinase inhibits tumor cell invasion in vitro and in vivo: Respective contribution of the urokinase plasminogen activator receptor-dependent or-independent pathway. Hum Gene Ther 16: 1157-1167,2005.

24. Liu D, Zhou D, Wang B, Knabe WE and Meroueh SO: A new class of orthosteric uPAR·uPA small-molecule antagonists are allosteric inhibitors of the uPAR vitronectin interaction. ACS Chem Biol 10: 1521-1534, 2015. 
25. Khanna M, Wang F, Jo I, Knabe WE, Wilson SM, Li L, Bum-Erdene K, Li J, W Sledge G, Khanna R, et al: Targeting multiple conformations leads to small molecule inhibitors of the uPAR·uPA protein-protein interaction that block cancer cell invasion. ACS Chem Biol 6: 1232-1243, 2011.

26. Kook YH, Adamski J, Zelent A and Ossowski L: The effect of antisense inhibition of urokinase receptor in human squamous cell carcinoma on malignancy. EMBO J 13: 3983-3991, 1994.

27. Ahmed N, Oliva K, Wang Y, Quinn M and Rice G: Downregulation of urokinase plasminogen activator receptor expression inhibits Erk signalling with concomitant suppression of invasiveness due to loss of uPAR- $\beta 1$ integrin complex in colon cancer cells. Br J Cancer 89: 374-384, 2003.

28. Nozaki S, Endo Y, Nakahara H, Yoshizawa K, Hashiba Y, Kawashiri S, Tanaka A, Nakagawa K, Matsuoka Y, Kogo M, et al: Inhibition of invasion and metastasis in oral cancer by targeting urokinase-type plasminogen activator receptor. Oral Oncol 41: 971-977, 2005

29. Kondraganti S, Gondi CS, McCutcheon I, Dinh DH, Gujrati M, Rao JS and Olivero WC: RNAi-mediated downregulation of urokinase plasminogen activator and its receptor in human meningioma cells inhibits tumor invasion and growth. Int J Oncol 28: 1353-1360, 2006.

30. Kunigal S, Lakka SS, Gondi CS, Estes N and Rao JS RNAi-mediated downregulation of urokinase plasminogen activator receptor and matrix metalloprotease-9 in human breast cancer cells results in decreased tumor invasion, angiogenesis and growth. Int J Cancer 121: 2307-2316, 2007.

31. Kargiotis O, Chetty C, Gogineni V, Gondi CS, Pulukuri SM Kyritsis AP, Gujrati M, Klopfenstein JD, Dinh DH and Rao JS: uPA/uPAR downregulation inhibits radiation-induced migration, invasion and angiogenesis in IOMM-Lee meningioma cells and decreases tumor growth in vivo. Int J Oncol 33: 937-947, 2008.

32. Raghu H, Gondi CS, Dinh DH, Gujrati M and Rao JS: Specific knockdown of uPA/uPAR attenuates invasion in glioblastoma cells and xenografts by inhibition of cleavage and trafficking of Notch-1 receptor. Mol Cancer 10: 130, 2011.

33. Duriseti S, Goetz DH, Hostetter DR, LeBeau AM, Wei Y and Craik CS: Antagonistic anti-urokinase plasminogen activator receptor (uPAR) antibodies significantly inhibit uPAR-mediated cellular signaling and migration. J Biol Chem 285: 26878-26888, 2010.

34. Mohanam S, Sawaya R, McCutcheon I, Ali-Osman F, Boyd D and Rao JS: Modulation of in vitro invasion of human glioblastoma cells by urokinase-type plasminogen activator receptor antibody. Cancer Res 53: 4143-4147, 1993.

35. Pass J, Jögi A,Lund IK, Rønø B, Rasch MG, Gårdsvoll H,Lund LR, Ploug M, Rømer J, Dan $\varnothing$ K, et al: Murine monoclonal antibodies against murine $\mathrm{UPA}$ receptor produced in gene-deficient mice: Inhibitory effects on receptor-mediated uPA activity in vitro and in vivo. Thromb Haemost 97: 1013-1022, 2007.
36. Nowicki TS, Kummer NT, Iacob C, Suslina N, Schaefer S, Schantz S, Shin E, Moscatello AL, Tiwari RK and Geliebter J: Inhibition of UPAR and UPA reduces invasion in papillary thyroid carcinoma cells. Laryngoscope 120: 1383-1390, 2010.

37. Hu J, Jo M, Eastman BM, Gilder AS, Bui JD and Gonias SL: uPAR induces expression of transforming growth factor $\beta$ and interleukin-4 in cancer cells to promote tumor-permissive conditioning of macrophages. Am J Pathol 184: 3384-3393, 2014.

38. Ragno P: The urokinase receptor: A ligand or a receptor? Story of a sociable molecule. Cell Mol Life Sci 63: 1028-1037, 2006.

39. Wei Y, Tang CH, Kim Y, Robillard L, Zhang F, Kugler MC and Chapman HA: Urokinase receptors are required for alpha 5 beta 1 integrin-mediated signaling in tumor cells. J Biol Chem 282: 3929-3939, 2007.

40. Carriero MV, Del Vecchio S, Capozzoli M, Franco P, Fontana L, Zannetti A, Botti G, D'Aiuto G, Salvatore M and Stoppelli MP: Urokinase receptor interacts with alpha(v)beta5 vitronectin receptor, promoting urokinase-dependent cell migration in breast cancer. Cancer Res 59: 5307-5314, 1999.

41. Tang CH, Hill ML, Brumwell AN, Chapman HA and Wei Y: Signaling through urokinase and urokinase receptor in lung cancer cells requires interactions with betal integrins. J Cell Sci 121: 3747-3756, 2008

42. Tsuji S, Kasumi T, Nagase K, Yoshikawa E, Kobayashi H and Kurita N: The effects of amino-acid mutations on specific interactions between urokinase-type plasminogen activator and its receptor: Ab initio molecular orbital calculations. J Mol Graph Model 29: 975-984, 2011

43. Kasumi T, Araki K, Ohyama T, Tsuji S, Yoshikawa E, Kobayashi $\mathrm{H}$ and Kurita N: The effects of vitronectin on specific interactions between urokinase-type plasminogen activator and its receptor: $\mathrm{Ab}$ initio molecular orbital calculations. Mol Simul 39: 769-779, 2013.

44. Ploug M, Østergaard S, Gårdsvoll H, Kovalski K, Holst-Hansen C, Holm A, Ossowski L and Danø K: Peptide-derived antagonists of the urokinase receptor. affinity maturation by combinatorial chemistry, identification of functional epitopes and inhibitory effect on cancer cell intravasation. Biochemistry 40: 12157-12168, 2001

45. Luther T, Magdolen V, Albrecht S, Kasper M, Riemer C, Kessler H, Graeff H, Müller M and Schmitt M: Epitope-mapped monoclonal antibodies as tools for functional and morphological analyses of the human urokinase receptor in tumor tissue. Am J Pathol 150: 1231-1244, 1997.

46. Wei Y, Eble JA, Wang Z, Kreidberg JA and Chapman HA: Urokinase receptors promote betal integrin function through interactions with integrin alpha3beta1. Mol Biol Cell 12: 2975-2986, 2001.

47. Mosmann T: Rapid colorimetric assay for cellular growth and survival: Application to proliferation and cytotoxicity assays. J Immunol Methods 65: 55-63, 1983. 